Historic, Archive Document

Do not assume content reflects current scientific knowledge, policies, or practices. 



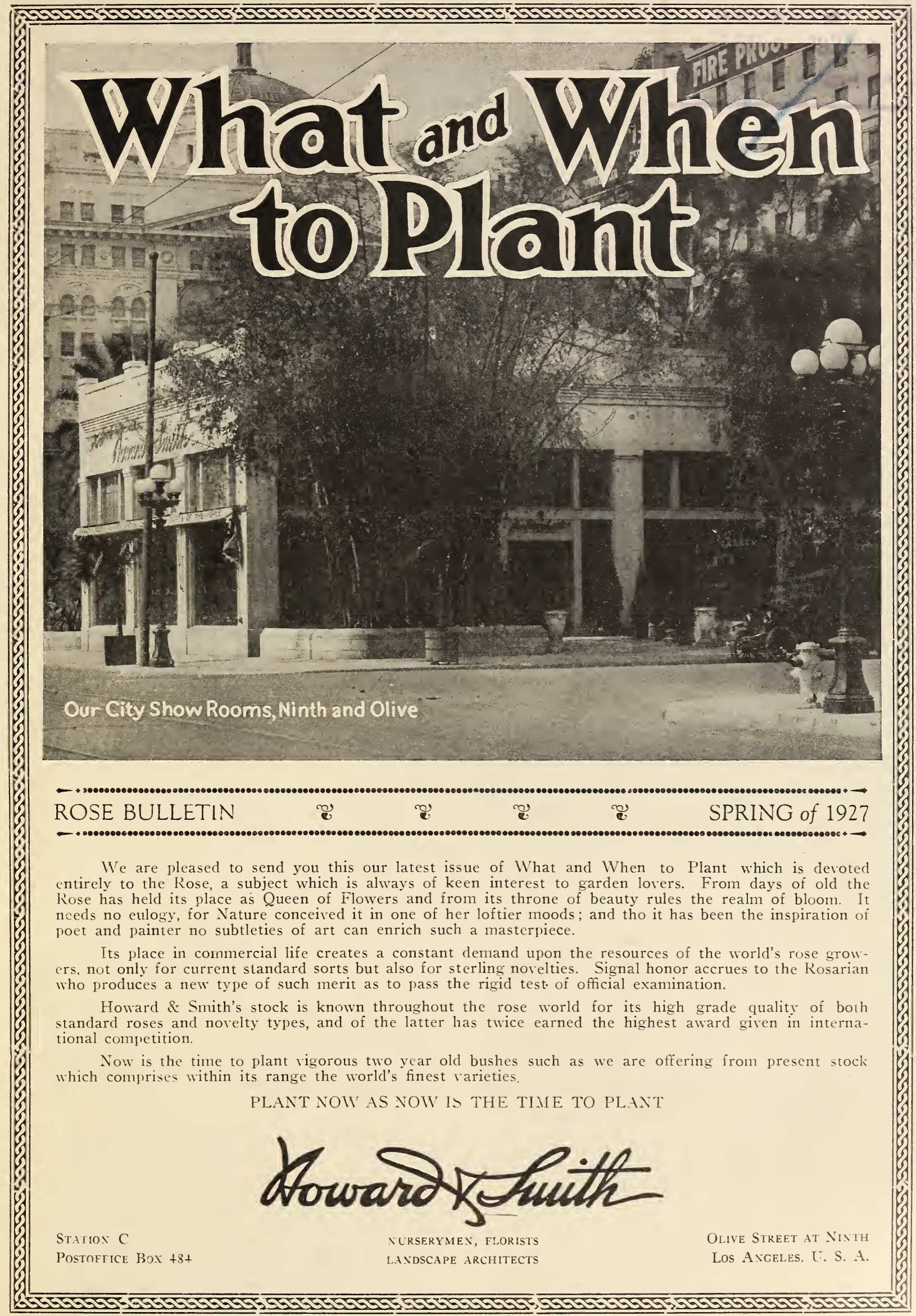




\section{The Rose}

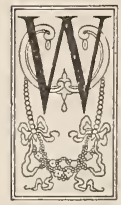

E have long made the rose our leading specialty and have for years devoted an immense amount of energy, time and money in developing the best method for the production of plants, as well as the testing out of the various novelties which appear from year to year both in Europe and America. In addition to this we have carried on extensive experimental work in the production of new hybrid roses of our own. The result we have obtained in the production of new varieties by means of scientific hybridization is well exemplified in such magnificent varieties which found their origin at our nurseries as Los Angeles, Miss Lolita Armour, Mrs. Lovell Swisher, Mrs. II. C. Egan, Josephine Thomas, Wm. F. Dreer and others. These roses through their own intrinsic worth have received recognition in all parts, two of them were awarded the premier gold medal at the International trials, Bagatelle Garden, Paris, France, an honor which has come to this country on three occasions only and was twice awarded to us.

By special arrangement with some of the leading European rose growers, whose novelties are world famous, we are able this season to place before you the very latest varieties, disseminating them here at the same time they are put on the market in Europe. This arrangement will prove of great advantage to our customers, as it will enable them to have their rose gardens replete with the latest improvements in this, the queen of flowers. In no single year in the history of our firm have we been able to offer you so many fine varieties, each and cvery one of which is worthy of a place in the finest collection.

One important feature of our roses is that they are all heavy two-year-old stock. They are budded low on vigorous growing Ragged Robin roots and possess a vigor which can only be imparted by such a stock as that upon which they are worked. They will give a larger and heavier production of bloom than any own root rose possibly could.

The list of varieties, which we submit for you $\mathrm{r}$ consideration, although not a long one, comprises such varieties which, after careful tests, we have found to be the best in their respective colors and general characteristics. With proper care, they will give you splendid results and with the recurrence of each season, an increased wealth of bloom.

\section{A Superb Collection of Novelty Roses for the Season of 1927}

ANGELE PERNET. One of the most remarkable pernetiana hybrids ever raised. This glorious rose was deservedly awarded the gold medal at the International trials at the Bagatelle Gardens, Paris, 1924. It is one of the most decided breaks by way of color in modern roses, the latter being a vivid orange flame with shadings of coppery apricot, with the exterior of the petals daintily suffused with pure gold. It is a rampant grower with dark glossy green mildew-proof foliage. Buds of perfect form, flowers fairly full with great freedom of bloom production throughout the year. A wonderful variety for bedding purposes. Price each, \$2.50.

CLIMBING LOS ANGELES. Howard \& Smith, 192.5. As an addition to the list of climbing roses this bud sport from the parent type, Los Angeles, is bound to prove one of the finest additions to the list of climbing roses offered in modern times. The flowers, if anything, are larger than those of the bush type; the same deep shades of coral, gold etc., are displayed in the blooms and buds in an intensified degree. We believe this climbing rose will prove one of the most popular of all climbing roses. The growth of the plants is exceedingly vigorous and it blossoms without intermission throughout the entire rose blooming season. A worth-while novelty.

Price each, \$1.50.
CLIMBING RED RADIANCE. Among the various bush roses grown today, there are but few which can exceed the prolific blcoming qualitics of either pink or red Radiance. In this $n$ w climbing sfort from th? well known Red Radiance, we have a rose which we believe is destined to become one of the most popular of all climbing roses of its particular color. The buds and blossoms are of enormous size and are produced in constant succession throughout a prolonged period. Roses of tha Radiance type are well known for their hardiness and we believe this superb new climbing form will be greatly welcomed, not only in the more temperate regions of the country, but in those sections where the winters are more rigorous in their nature. It cannot be too highly recommended.

Price each, \$2.50.

CLIMBING SOUV DE H. A. VERSCHUREN. Howard \& Smith, 1927. This lovely climbing rose occurred as a branch sport from the well known popular rose of the same form, which was introduced from Holland in the season of 1924. The flowers, if anything, are larger than those of the dwarf type, the color is a lovely two-toned yellow, the center being a beautiful shade of apricot yellow, shading to saffron at the edges of the petals. Buds are of large size and perfect form. The fully dercloped flower is of immense size, and we 
Fredict that this will prove one of the finest of all yellow climbing roses, entirely displacing such sorts as Cli. Sunburst etc.

Price each $\$ 2.50$.

DAME EDITH HELEN (A Dickson \& Sons 1927). Te particularly direct your attention to this magnificent rose, a new gold medal varietyand the winner oi many other sicnal honors in England during the season of 1926. The must frantly coniess that any description. no matter how well worded, can ever adequately convey any commensurate idea of its regal beauty. It is a rose. as near as we have been able to observe, that is without a fault. The plant is of extremels vigorous growth, well furnished with larze dar' green leathery foliage. The immense buds are borme singly on upright canes aiter the manneof some of the hybrid perpetuals such as American Beauty. and expand into an open flomer of impressive size and beauty.

The color is a matchless shade of pure pink, mellow in tone and rich to the last desree. We know oi no other rose which can approach its superb shade. In form, either in bud or open bloom it is well nigh periect and last but not least it has an additional qualification only too often lacking in modern roses. FRAGRANCE. Te do not believe there is a rose in existence wherein the odor is more intense. It has the same delicious odor as that of the old damask rose. A tew fowers will scent a whole room.

To conclude. we would add that it is a rose which "grows old gracefully." It holds its superb shade of pink from opening bud till the last petal drops

each $\$ 5.00$.

\section{DORIS TRAYLOR (McGredy).} Fich, slowing carmine pink flushed crimson and orange. Flowers larze and iull. Buds long and pointed. This is a new rose of the most beautiivl color, and as a iree flowerin = variety. has few equals. Highly re. commended.

Price each. $\$ 1.50$.

EMILE CHARLES. A recent

French introduction with very high-

ly colored buds and open fiowers. The buds are a ficry red shade. with a suffusion of golden yellow. As the fiowers develop the color changes to a superb coral red

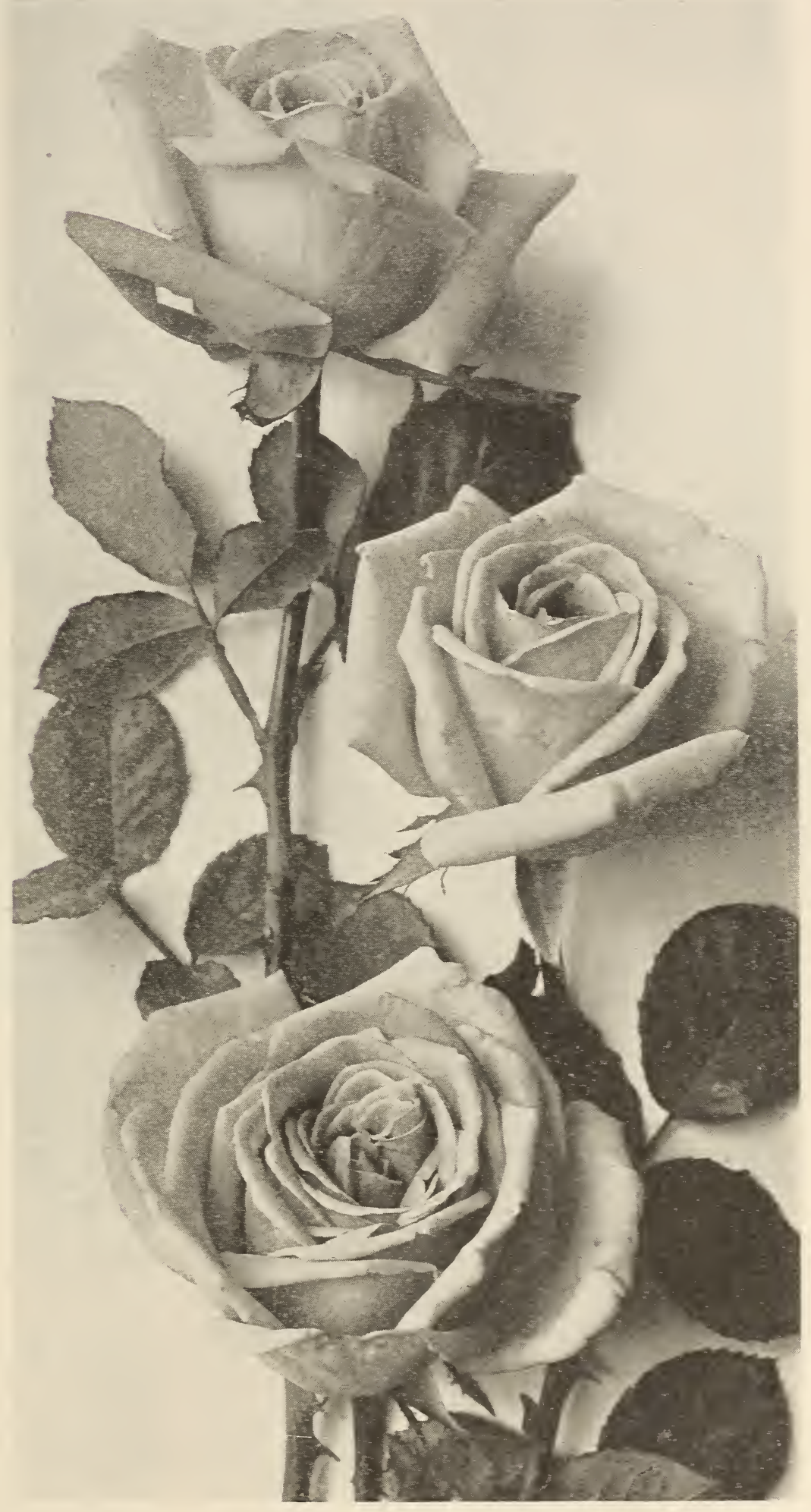

Dame Edith Helen with shadings of strawberry red at the extremity i
petals Growth fairly vicorous. Tery izee fowering

Frice each $\$ 1.50$ 
EVA TESCHENDORFF. A new bedding rose of the polyantha class bearing immense trusses of snowy whit? flowers throughout the whole rose b'ooming seasc 11 . The individual flowers are similar in form and size to those of the well known variety Lafayctte. A uniqu: and bcautiful effect may be obtained by planting it alternately in a row with Lafayette as a border to rose b ds of the taller growing sorts. A very fine bedding rose which is constantly in bloom. Height abont $2 \frac{1}{2}$ fect.

Price each 75c.

FRANK READER. This is a 1927 novelty and onc of the finest tivo-toned yellow roses that we have ever had the pleasure of sending out. Most people are acquainted with the old variety Sunburst. This now varicty might be referred to as a glorified type, of the sume color. In the 1926 Summer show of the Royal Horticultural Socicty of England, it was awarded the well deserved honor of a first class cartificate. It has a large massive bud with a high pointed center which opens to a flower of very large size. The heart of it is golden apricot and shades lighter town $\mathrm{rd}$ the exterior of the petals. Deliciously apple sennted. This rose will prove a splendid variety for cut flower purposes. It is one of the most profusely blooming roses of its color that we know of. The plants are of strong upright growth with splendid clean-cut frliagc. A rose for everybody's garden.

Price each \$2.50.

GWEN NASH. A new rose of sterling worth and in our opinion one of the most beautiful climbing ö pilar roses ever offared to the rose-loving world. The blossoms are borne in large trusses at the terminals of strone vigorous growing canes. The buds are long and point $d$ and expand to flowers having a diameter of 5 to 6 inches. At certain seasons they average even larger $t^{\wedge} n$ this. The color of the upper portion of the petals is an cntrancing shade of pure soft cyclimen pink. while the center of the flower is a corona of pure white, the zones of color being about equally divided over the surface of the flower.

Price each \$1.50.

IRISH CHARITY (McGredy, 1927). A frec blooming variety with blooms of moderate size. In color a wonclerful shade of intense ficry scarlet changing to rosy scarlit as the b!coms matur?. A strong, vigorous grower well furnished with handsome foliagc. Price each $\$ \mathbf{2 . 0 0}$.

IRISH CHARM (McGredy, 1927). Buds and open blooms of moderate size and absolutely perfect form. Base of petals rich golden apricot passing to a delicatc blush pink in the fully developed bloom. A strong vigorous grower of fine branching habit. Very fragrant. A splendid bedding rose.

Price cach $\$ \mathbf{2 . 0 0}$.

IRISH HOPE (McGredy, 1927). Another splendid addition to the list of red roses and quite distinct from all others of its particular color class. The buds are well formed and expand to very large broad petaled blooms. This rose was greatly admired in our trial beds during the past season. Its brilliant shades attract the cyc at once. Color rich, rosy crimson.

Price each $\$ 2.00$.

IRISH MORN (McGredy, 1927). This new rose is one of particular grace and charm, its color being a delightful rich pink deepening to coral at the base of the broad cupped petais. The buds are long and pointed, the growth strong and of branching habit. Altogether a worth-while variety.

Price each $\$ \mathbf{2 . 0 0}$.

IRISH SWEETNESS (McGredy, 1927). One of the frec-est blooming red roses in our entire collection, and one which we feel certain will be much sought after when $\mathrm{b}$-tter known. The shade of red to be noted in this rose is similar to that of the well known variety, Laurent Carle, being crimson lake with a suffusion of scarlet. Buds of moderate length. Expanded bloom large and of a telling color.

Price each \$2.00.

J. OTTO THILOW. During the past scason in the test pots at our Rivera plant, we had several hundred stocks of this superb novelty. It is a pink varicty and one of the deepest shades of rose pink, several tones d?rker than the well known varicty, Rose Marie. The buds and open flowers are simply perfect. In bearing qualitics the variety has but few cquals, being covered with masses of perfect buds and bloons during the whole rose ycar. Its shade of rose is absolutely even from the time it begins to expand until it reaches the stage of a full developed flower. A superb variety for cut flower purposes.

Price each \$2.50.

JOSEPHINE THOMAS (Howard \& Sminh). This novelty rose is one of our own seedlings and has been named in honor of the daughter of the well known rosarian, Capt. Geo. C. Thomas. It is a varicty with strong vigorous habit and absolutely perpetual blooming in its character. The buds are long with high pointed centers, the open b'oom large and full, with petals bcautifully reflexed. The buds are cream flesh in color, with the half open flowers displaying a light orange salmon-colored center. We feel quite certain this will prove a splendid garden rose on account of its frectom of bloom and equally valuable as a cut flower.

Price cach $\$ \mathbf{1 . 5 0}$.

JOHN RUSSELL. An immense sized dark velvety crimson rose, winner of the gold medal at the Inter11ntional Trials at the Bagatelle Gardens in Paris, 1924. This varicty is a strong vigorous grower, canes bcing furnished with ample leathery dark green foliage. Flowers are borne at the terminals of its strong cancs and are of phenomenal size and beauty. The color is not unlike that to be noted in the variety, H. V. Machin, if anything, is richer in its tone. During the Fall months the color deepens, the scarlet $b$ ing overlaid with rich maroon red. This rose is a very tall grower and should be used as a back row subject in the rose garden.

Price each $\$ 2.50$.

LADY MARGARET STEWART (Alex Dickson \& Sons). This magnificent novelty is unquestionably one of the most remarkable and distinct roses of the new hybrid pernetiana class and well deserving of the gold medal awarded by the National Rose Socicty of England during the 1926 Spring Show. The flowers are full and double, the bud long and pointed. In the bud stage, the color is a delightful shade of sunflower ycllow, heavily veined and splashed with orange scarlet. As the blossoms mature, the general (ffect of color is that of orange cadmium and apricot. Foliage mildsw-proof. A constant producer and invaluable as a cut flower or bedding rose

Price each $\mathbf{\$ 2 . 5 0}$. 


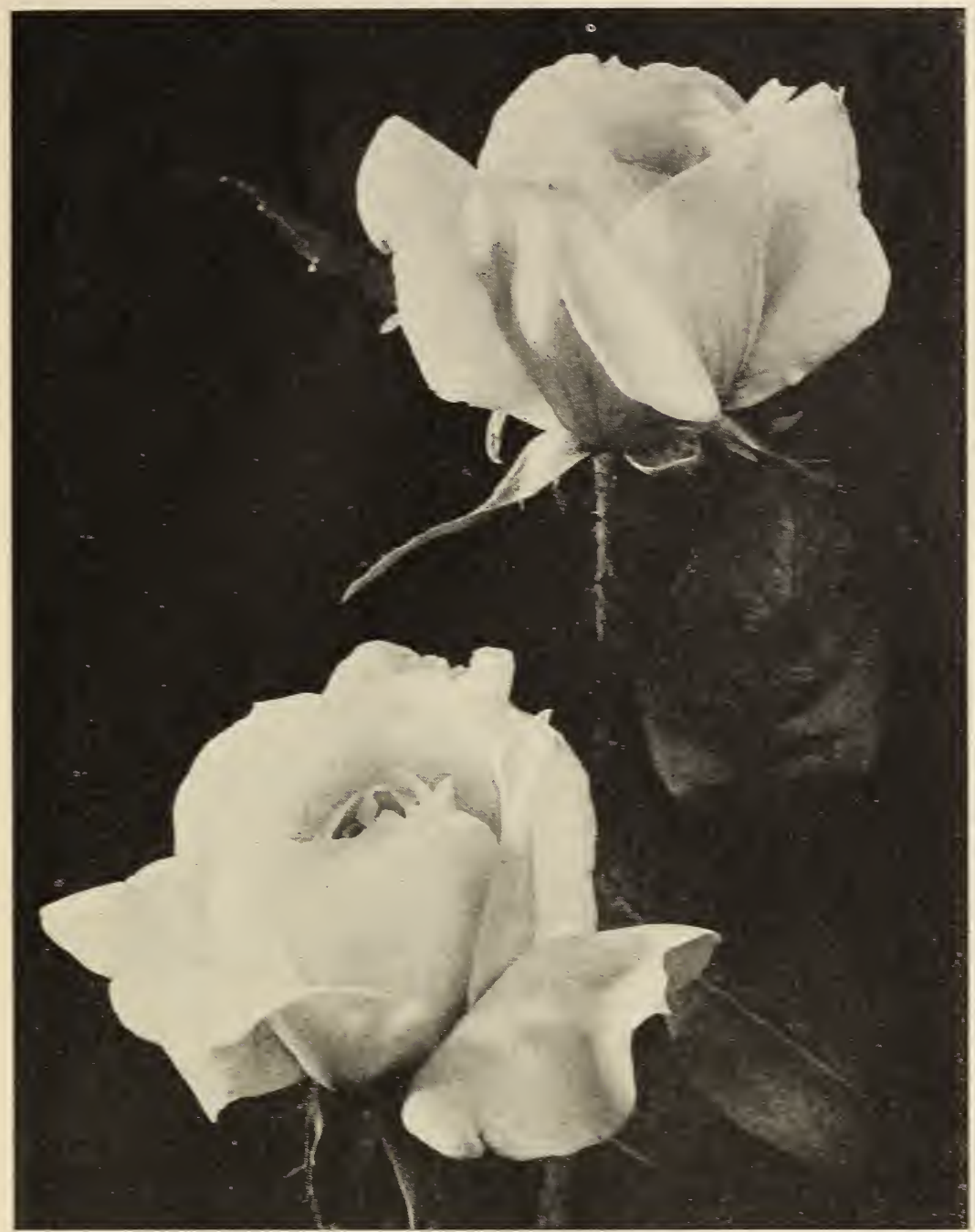

Mad. Albert Barbier

LADY FLORENCE STRONGE (McGredy). This is another of the new Irish roses and a splendid addition to our novelty sheet for the season of 1927. We quote the raiser's description: "The color is reddish prawn to violet old rose. shading at the base of the petals to yellow and towards the edge, to pink, the inner surface of the petals being heavily veined and slightly ilushed scarlet. An indescribably beautiful combination of color." TTe can only add, it is a rose of splendid quality and one which is destined to grow in popular favor. The growth is iree and bushy and the flowers are carried upright on stout stiff stens.

Price each $\$ 1.50$.

MRS. A. R. BARRACLOUGH (McGredy, 1926). A sold medal winner before the National Rose Society of England and well worthy of the award given. This rose is a rampant grower and bears flowers and buds of phenomenal size. In general form and contour the buds and blossoms are not unlike those to be noted in the variety. Souv: de Georges Pernet, but the growth of the plant as a whole is stronger and more upright than that of the former variety. The combination of colors to be noted in this rose are most difficult of description. A soft sparkling carmine pink, with suffusions of salmon, the whole merging to yellow at the base of the petals. Last. but not least, it has the merit of being very fragrant.

Price each $\$ 2.50$.

MRS. C. W. EDWARDS. Since the introduction of hybrid roses of the pernetiana class many colors and combinations of colors, hitherto unknown in roses, have become afparent, the variety in question bein one which forcibly illustrates the point. It is distinct from any other rose we hnow of by way of color. the latter being a pure crimson ca:mine with a solden yellow base to the petals. The flowers are large. full. sweetly scented and the foliace not subject to mildew.

Price each \$1.50.

MRS. ERSKINE PEMBROKE THOM (Howard \& Smith). In our rield trials of new roses during the past season, this variety stood out pre-eminently as one of the free-est and most vigorous growing of all vellow roses. The had row of it some 500 feet long which were a mass of solden yellow throughout the whole season. 11 e might add that it was one of the most admired of all the numerous novelties at our rose fields during 1926 .

Price each $\$ 2.00$.

MRS. HENRY BOWLES. A replica by way of color of the well known old variety Mad. Abel Chatenay, the color a beautiful shade of salmon pink. Buds and flowers of large size, the latter composed of broad cupped petals. A vigorous grower constantly in flower, perfect in all its stages of development. A grand variety for cutting

Price each $\$ 1.50$.

MRS. LOVELL SWISHER (Howard \& Smith, 1926). A glorious new seedling of our own raising. obtained as the result of a cross between the variety. Grange Colomb $x$ Souv. de Claudius Pernet. The blosson has inherited the magnificent long pointed bud of its seed parent, but in color it is at wide variance with that of the pollen plant. The color is a deep coppery salmon. passing in the exterior of the petals to delicate salmon pink and Hesh at the edges. The base of the petals in the bud is golden ochre, the same color manifesting itself in the base of the fully opened flower. We know of no rose wherein the bud is of more exquisite iormation than in this lorely variety. It is a rampant grower and bears an endless succession of perfect flowers throughout the intire season. We cannot recommend this variety :0o highly, and we feel that those who try it will more than asree with us that we have given to the rose-loving world a rose which will take its place with such varieties of our own introduction, as Mrs. M. C. Esan. Los Anseles, etc. See cut on page 13 P-ice each $\$ 2.00$. 
MISS MARION MANNIFOLD (Adamson). A grand new climbing rose of Australian origin. The plants are of extremely vigorous growth and carry their splendid big b!ooms in constant succession throughout the entire season. The color is a brilliant crimson scarlet of a quality which does not fade or "Blue." The flower is fairly full and of most refined form and finish. For pergolas, trellises, etc., this splendid variety is sure to find first place. Very sweetly scented. Price each \$1.50.

MRS. W. E. NICKERSON (McGredy, 1927). A superb rose in every sense of the word. It is an extremely vigorous grower with buds and open b:ooms of exquisite form and texture. The basic color is a rich, warm. rosy salmon fiushed and shading to deep chrome yellow at the heart of the flower. The exterior of the flower when in bud form shows a rich orange cadmium at the base which gradually merges into the salmon of the upper portion of the bloom. This rose is not only of b autiful and cistinct color arrang ment, but has the additional good qualities of being a rampant grower with a freedom of bloom production equalled by but few other sorts. A grand variety for cutting purposes.

Price each $\$ 2.50$.

MARY PICKFORD (Howard \& Smith, 1926). We named this rose in honor of "America's Swectheart" It has a dainty flower of moderate size equivalent in this respect to the well known variety, Mrs. Aaron Ward. The color is a decp, rich orange without any shadings whatever, many shades darker than the color to be noted in the well known variety, Souv. de Claudius Pernet. For corsage work this lovely sort will prove invaluable. It blossoms freely throughout the entire season. The plant is of vigorous nature, much more so than any other orange colored rose we know of. The foliage is ample, rich dark glossy green in color. Although not a large flower, there is a refinement about this rose, which carries its own appeal. Price each $\$ 250$.

MABEL MORSE. Clear, brilliant golden yellow without a trace of any other color to mar its beauty. Flowers of moderate size well formed both in bud and open bloom. Foliage bright, glossy green mildew-proof. Growth moderate. Taking all its points, it is a rose of great merit and should be in every first class collection.

Price each $\$ 1.50$.

MAD. ALBERT BARBIER. One of the most noteworthy novelties in roses obtained in many years. It is a seedling from Frau Karl Drushki and possesses the sturdy character and free blooming qualities for which the latter variety has long been noted. The bush is of upright growth, having more the character of a hybrid perpetual than a hybrid tea, and blossoms without intermission throughout the season. The buds are of exquisite formation and display a color which will appeal to the most esthetic, being a pearly white suffused with soft flesh pink, with darkest shadings of golden apricot at the base of the petals and center of the flower. We have seen no other rose wherein the blendings of color are like this one and few, if any, regardless of color, more beautiful.

Price each $\$ \mathbf{1 . 5 0}$.

NORMAN LAMBERT (McGredy). A new pernetiana hybrid of distinct and novel colorings, the outside of the petals being a deep chrome yellow with a marginal color effect of brilliant orange scarlet, merging to an irregular zone of burnt orange. The interior of the petals is salmon orange, with bronze suffusion shaded yellow at the base. The flowers are of medium size, delightfully fragrant and especially free flowering.

Price each $\$ 2.00$.

PHYLLIS BIDE. A splendid ever-blooming polyantha rose. Blossoms are about the same form and size as the well known Climber, Mad. Cecil Brunner. They are produced in loose sprays at the terminals of long branching shoots. Color is a neat shade of pale gold at the base, shading to carmine pink at the exterior edges of the petals. Unlike most of the hybrid polyantha roses, this variety is constantly in bloom, which gives it a desired advantage as a climbing rose for pergolas, trellises, etc. The whole effect of a plant of this variety in bloom is dainty in the extreme. Price each $\$ \mathbf{1 . 5 0}$.

PINK PEARL. One of the most desirable qualifications to be wished for in a rose is that of fragrance, and in this new variety from Holland, we have it in an intensively accentuated form. This rose is not only beautiful with respect to color and general form, but it has a fragrance so intense in nature that a few blossoms cut and placed in a vase will scent a whole room. It has often been thought that climatic conditions were responsible for the fragrance or non-fragrance of roses, but such is not the case. Many varieties are absolutely deroid of fragrance no matter where grown; others have it in various degrees and in this particular variety it is a highly developed factor. Aside from fragrance, it is a flower of beautiful form and build, moderate in size, a delightful rich cerise pink in color, merging to gold at the base. A tremendously vigorous grower, bearing a constant succession of buds and flowers throughout the season.

Price each $\$ 2.00$.

SHOT SILK. (Alex Dickson \& Sons). This rose has been well named. The blendings of color to be noted in the open flower are difficult to portray. The ground color is a bright shade of cherry cerise over-shot with salmon orange, flushed rose and deeply veined with clear buttercup yellow at the base. The foliage is a clear, bright glossy green, free from mildew. It is free in bloom with flowers carried erect on strong stiff canes. The petals are large, very broad and exhale a strong rose perfume. The color is more or less variable, the tints being especially fine during the early Spring and Autumn months.

Price each $\$ \mathbf{1 . 5 0}$.

SIR DAVID DAVIS (McGredy, 1926). This is another splendid crimson rose, a color for which there is always a great demand. It is a variety which we are certain will take a permanent place amongst the popular varieties of its particular color, the latter being an unfading deep glowing crimson of an even shade throughout the flower. The open flowers are very large and full, the buds long pointed and of a fine form. Foliage bright green in color, the stems having but comparatively few thorns. Our trial rows of this varisty during the past season were a constant wealth of color. The flower is deliciously fragrant, in fact, it is one of the sweetest scented crimson roses that we have ever grown.

Price each \$1.50.

THE BEACON. A fine pillar rose with bright fiery red flowers with a zone of pure white in the center of the bloom. Flowers single or semi-double produced in large clusters. Foliage large and handsome, bright, glossy green in color. A very effective climbing rose.

Price each $\$ 1.00$ 


\section{Roses of Recent Introduction and the Best of the Tried and True Standard Varieties}

Included in the following list are varieties of exemplary worth, embracing the best of the hybrid teas and hybrid pernetianas. There is not a vario y we offer you below that is not worthy of a place in the best rose garden. We doubt if a finer assortment of varieties can be found anywhere. The selection of these sorts is based on a life-time experience and intimate knowledge of roses. We feel sure customers purchasing them will find their confidence has not been misplaced.

BETTY. A superb rose with blooms of the most exquisite color imaginable. Copper rose shaded golden yellow at the basc. Buds long and pointed. A rigorous grower.

Price each $75 \mathrm{c}$.

CAROLINE TESTOUT. An old but still one of the best pink roses. Color, a delightful shade of glistening silvery pink. A constant mass of bloom throughout the entire season.

Price each $75 \mathrm{c}$.

CONSTANCE. Easily one of best deep yellow roses grown at the present time. As far as our observation gocs, it is a varicty without a fault, either in respect to its color or other points applying. In color a shade of deep rich orange with shadings of chrome. The reverse of the buds shaded with crimson. Buds long and pointed, expanding to a large petaled flower. Highly recommended.

Price each \$1.00.

DUCHESS OF WELLINGTON. Intense saffron yellow stained with crimson. As the flower ages it becomes a deep saffron yellow. Blooms fairly full. Buds long and pointed. Very free flowering. Exceedingly fragrant.

Price each 75 c.

EDEL. One of the finest additions to the class of light colored roses introduced in many a day. The buds are long and pointed. In color, pure white. As the flow:r expands, delicate tints of irory manifest themselves in the center of the flower. These in turn, howexer, are lost as the flower expands, the open bloom being practically snow white. It opens somewhat flat in form, but is a rose of perfect contour, splendid growth with a pronounced freedom from attacks of mildew in the foliage.

Price each $\$ 1.00$.

ELDORADO (Land of Gold). Howard \& Smith, 1923. Another of our own introduction which we feel will please the most exacting rose lover. Flowers large and full, deliciously scented. In color, a glorious shade of golden yellow, the edges of the petals at certain seasons tinted with deep pink. The blossoms are a counterpart of Miss Lolita Armour in form, growth exceedingly vigorous. This rose has made a record for itself not only in America, but Europe as well. Price each \$1.00.

FLORENCE PEMBERTON. Silvery pink on a white ground. A rose remarkable for its large size and handsomely forme blooms. An exceedingly vigorous grower.

Price each $75 \mathrm{c}$.

FRAU KARL DRUSCHKI. One of the grandest hybrid perpetuals in existence. It produces very large snowy white blooms and is beautiful either in the bud or fully expanded state. In its full blown state the blooms greatly resemble a snowy white paeony. They are of huge size and as handsome as they are big.

Price each $75 c$.
GENERAL McARTHUR. Bright crimson. One of the best of all red roses for bedding purposes. Not subject to mildew. Blooms continuously over a long period.

Price each $75 \mathrm{c}$.

\section{THE ROSE Queen of Flowers LOS ANGELES Queen of Roses}

This superb rose which we introduced in the year of 1917 has made a record for itself in all parts of the world where roses are grown and appreciated for their beauty and fragrance. We believe we can say without egotism that it is a rose which has come to stay. It has received recognition from rose societies and rose lovers everywhere. It was awarded the gold medal at the International trials in Paris in 1918 and has more than fully borne out the high merit accorded it. VIe doubt if there was ever a rose introduced for which the demand has been so heavy, due entirely to its generally recognized high-class qualities. It possesses a color absolutely new in roses-luminous flame pink toned with coral and shading to translucent gold at the base of the petals. The buds are long and pointed and expand to a flower of mammoth proportions. It is beautiful from the opening bud until the last petal drops. It is a rose that will furnish you from plants grown in your own garden better flowers than can be produced from under-glass grown stock. Our culture of this variety alone at the Fernando grounds during the past season exceeded 35,000 , which is indicative in some mea sure of the popularity of this glorious rose. A remarkable feature of Los Angeles is the fact that it can be grown in all climates. It does well in temperate climates, such as that of California, yet it is quite hardy under the harsh conditions of cold, etc., which are per. tinent to the most easterly portions of the country. It is a rose that everybody can grow. It is a rose without which no collection is complete. Price each $\$ 1.00$. 
GRUSS AN TEPLITZ. The most profuse blooming velvety crimson rose in existence, besides which it possesses an admirable constitution, a point lacking in many red roses. Has good, clean foliage, and throws strong, upright canes. A grand garden rose. Price each $\mathbf{7 5 c}$

HARRY KIRK. A splendid addition to the none too long list of good yellow roses. Deep, rich, buttery yellow in color, shading lighter at the tips of the petals. The buds are perfection in form. Price each $\mathbf{7 5 c}$.

HADLEY. In color, rich, dazzling crimson scarlet with shadings of velvety crimson. A deliciously fragrant, vigorous growing rose.

Price each 75 c.

HOOSIER BEAUTY. A rose of American origin and, in our opinion, one of the finest red hybrid tea roses in existence. Flowers of superb form not unlike a perfect Sunburst in shape. They are beautiful either in the bud or in the fully expanded bloom. The tone of color is one of those rich, dark, velvety reds not unlike that to be noted in the old variety Black Prince. A perpetual bloomer.

Price each 75 c.

IRISH FIREFLAME. An exquisite single rose that should be in every garden. Color, a deep maddery orange, splashed with crimson, deliciously and strongly perfumed. Vigorous in growth, constant in bloom.

Price each 75 c.

JONKHEER J. L. MOCK. A rose of giant size. Enormous, deep rose colored blooms, surmounting strong, vigorous canes.

Price each 75c.

JOSEPH HILL. Pink shaded with salmon. Exterior of the petals coppery pink. Superb either in bud or open flower. A truly magnificent variety. Price each $75 \mathrm{c}$.

KAISERIN AUGUSTA VICTORIA. Creamy white in color. Grand in form, free in growth; one of the best all around whites for cutting purposes. Price each, $75 c$

LADY ALICE STANLEY. In color an exquisite shade of coral rose, the inside of the petals shading to flesh pink. Blossoms very large, exceedingly fragrant. A very desirable variety.

Price each $75 c$

LADY HILLINGDON. Deep apricot yellow. Long, pointed buds. Produces enormous quantities of flowers with buds of especially fine shape. Well adapted for use as a cut flower.

Price each 75c.

LADY URSULA. Flesh pink, possesses a delicate tea perfume. A rampant grower, always in bloom.

Price each $75 c$

LA CHAMPAGNE. A superb novelty rose, the ground color of the flower being a soft, satiny salmon pink, exquisitely shaded with salmon and apricot. Bas $\epsilon$ of the petals deep orange. An unusual combination of colors, and as beautiful as it is unusual. A good, vigorous grower and a constant bloomer. Highly recommended.

Price each $\$ \mathbf{1 . 0 0}$.

LAFAYETTE. Among all the various varieties of polyantha roses introduced in modern times, this is easily one of the very best. The flowers are quite large-almost the size of the Paul's Scarlet Climber-and have the same rich crimson scarlet color. The plants are absolutely perpetual in their blooming character. They attain a height of some 3 feet and bear without intermission magnificent trusses of bloom throughout the entire season. It is a rose of unexcelled value for borders or for any place where a dwarf bedding effect is desired. Planted in masses by themselves, it will flower as freely as a geranium. The trusses clean nicely. The appearance of a bed in bloom is always fresh and bright. Price cach 75c.

LULU. A new rose of English origin and to our mind one of the most distinct roses in cultivation today. The buds are long and pointed, in general formation and shape are similar to Irish Fireflame, but of even more beautiful form. In color a lovely shade of pure apricot. This rose is only of use in the bud form, but we doubt if there is a rose in existence today of more beautiful effect when cut in bud form and used in corsages, bridesmaid bouquets, etc. It is more double than Irish Fireflame, more or less similar in growth, a constant bloomer.

Price each \$1.00.

LAURENT CARLE. In color, bright red. A very free bloomer. Nildew proof, extra fine for bedding. Price each 75c.

LOUISE CATHERINE BRESLAU. A magnificent rose belonging to the pernetiana class. Buds a beautiful shade of coral red toned with chrome yellow. When fully opened the flower changes to shrimp pink and coppery orange; a sensational and exquisite variety.

Price each, $\$ 1.00$

MAD. EDOUARD HERRIOT. Superb coral red shaded with yellow at the base of the petals. Sensational in color; a good grower and a free bloomer. Mildew proof foliage.

Price each $\mathbf{7 5 c}$

MAD. JULES BOUCHE. A very strong growing variety. Good either in the bud or fully expanded flower. Ground color of the flower is pure white with blush tints.

Price each, 75c

MAD. LEON PAIN. Light silvery pink shaded with salmon. Growth exceedingly vigorous and produces large quantities of flowers throughout the entire season. We consider this an indispensable variety to any collection of roses.

Price each, 75c

MAD. SEGOND WEBER. Magnificent light rosy salmon. Buds long and pointed, expanding to flowers of immense size. In this particular color there is nothing to equal it.

Price each, 75 c

MRS. AARON WARD. Deep, rich Indian yellow toned with salmon. It is a constant bloomer with buds and open blooms of most refined form. A favorite everywhere.

Price each, 75c

MRS. A. R. WADDELL. Deep reddish apricot toned with salmon. A vigorous grower, constant bloomer and, incidentally, a wonderful advance in roses by way of color.

Price each, 75c

MRS. CHAS. RUSSELL. A splendid rose for cutting purposes. Blossoms intensely fragrant. Beautiful in bud or fully developed form. Color, deep rosy carmine.

Price each, 75c

MRS. FRANKLIN DENNISON. The color of this variety is difficult to describe, the base of the petals being a rich chrome yellow, which gradually merges to light silvery pink. Bud and flowers of enormous size quite double. Intensely fragrant. rrice each, $75 \mathrm{c}$ 


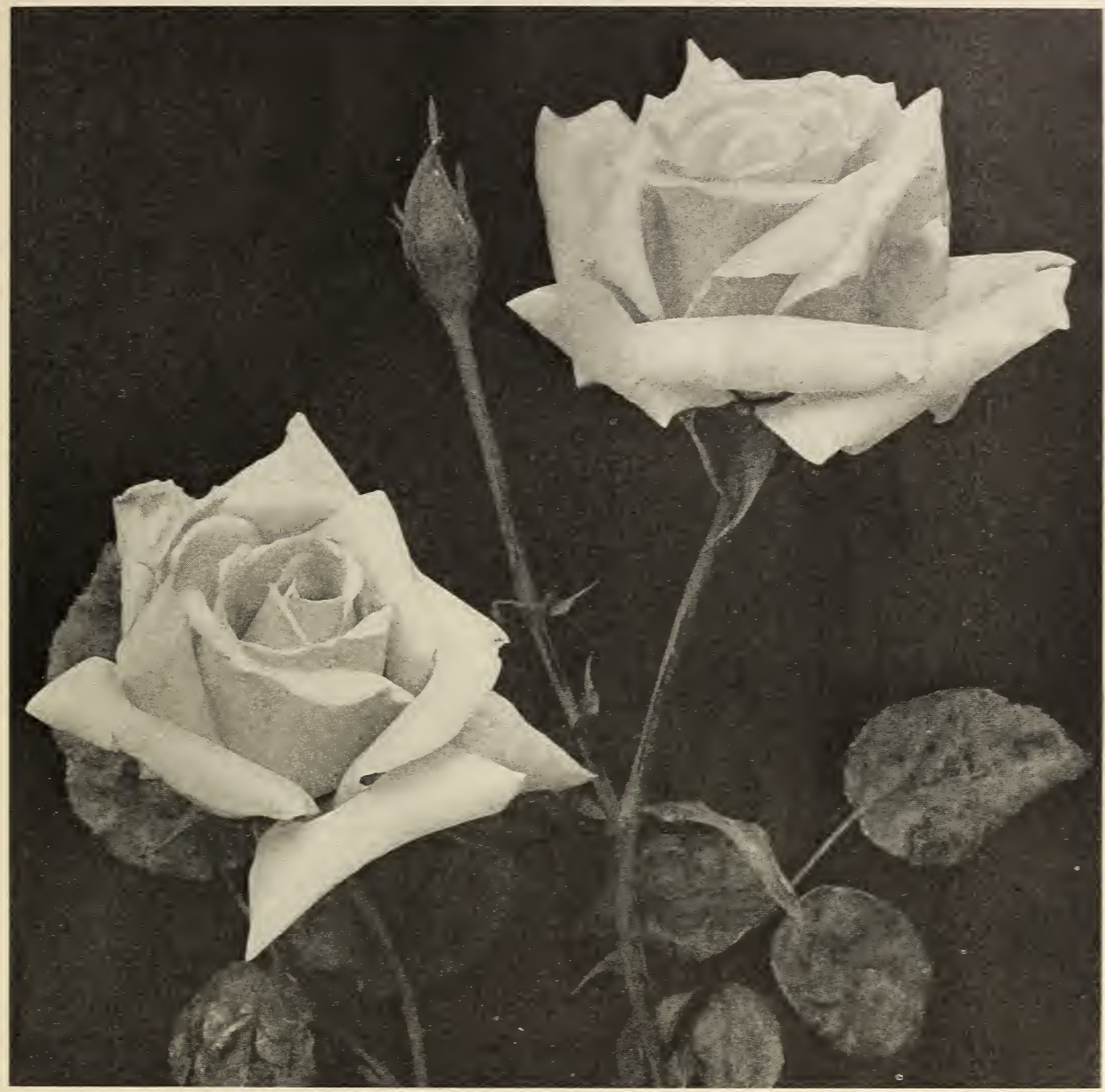

Mad. Jules Bouche

MRS. HENRY MORSE. A new rose of superlative merit; in our opinion a top notcher in roses of its particular color. the latter being a lovely shade of bright rose. with clear vermilion veinings on the petals. Perfect as to shape, magnificent as to form, either in the bud or open flower, with a freedom of blooming and habit of growth which cannot be excelled. Immense as to its size. Very fine.

Price each $\$ 1$. Co

MRS. REDFORD. A new rose of the pernetiana class. with splendid shiny dark green follage. Mildew proof in every sense of the word. Bears splendidly formed buds and open blooms in a lovely and striking shade of orang: apricot. The half open buds are simply superb in their form and contour. A sterling and distinct novelty rose that should be in every garden. It is a rose without a fault.
Price each $\$ 1.00$
MRS. W. C. EGAN (Howard \& Smith, 1922). This rose is another of our own hybrid seedling introductions and one which we believe will prove lasting in its popularity: The color is a lovely shade of two-toned fink. shading through deep tlesh to golden yellow at the base of the petals. Although only in commerce since 1922, this rose has already gained a splendid reputation for itseli. The contour of its long. pointed buds and the splendid formation of the open bloom with its glorious combination of colors will appeal to everyone. Price each $\$ 1.00$.

MRS. W. C. MILLER. A pink rose somewhat after the style of Caroline Testout. but much deeper shade of pink. A curious feature of this rcse is the crinkly and wavy outline of the edges oi the petals. Price each 75 c. 
OPHELIA. Salmon flesh shaded with rose. Buds of absolutely perfect form; a splendid rariety for either in door or outdoor cultivation.

Price each $75 \mathrm{c}$.

PADRE. The race of pernetiana roses has given the rose worid some wonderful new colors and combination of colors which prior to their introduction were hitherto unknown. Among the large number in this class which has been presented to the rose-loving world there are none we know of more distinct than this lovely variety. The color is very difficult of description, but might be alluded to as a coppery orange crimson with shadings of yellow at the base of the petals. The habit is erect, the flowers are borne on splendid stems and it is exceedingly free flowering, beautiful either in the bud or fully expanded flower. As a rose for use as a cut flower or for its effect as a blooming plant in the garden it is without a peer. The petalage is moderately full, the buds long and pointed. A variety of exquisite effect any way you take it. A strong, vigorous grower, highly recommended.

Price each $\$ 1.00$.

PRESIDENT CHERIOUX. One of the most remarkably-colored roses introduced in modern times. The color is a beautiful shade of prawn red, toned with salmon and shaded with deep yellow. Flowers large and globular. well formed, a variety which is bound to find many arlmirers on account of its unique combination of colors $A$ good grower and very free.

Price each \$1.00.

RADIANCE. A rose of American origin, and to our mind one of the best varieties in cultivation today. Buds long and pointed, expanding to blooms of enormous size, similar in shape to Caroline Testout, but in color deen, rich rose pink.

Price each 75c.

RED RADIANCE. A counterpart of the original pink variety, save color, which is a delightful shade of rich rosy red. Tremendously vigorous grower and constant bloomer. Price $\cong$ ach 75 c.

REV. F. PAGE ROBERTS. Among our extersive trials of new roses during the past season this splendid variety has shown up remarkably well. It is a rose distinct from anything else in our entire collection by way of color, the latter being a rich buttery Marechal Neil yellow. The blossoms are not only rich and handsome in proportion, but have a rich, fruity fragrance distinct from that to be noted in any other rose. The foliage is glossy, frec of mildew; the plants extremely vigorous and the flowers open well in all kinds of weather. A rose which has come to stay. $\quad$ Price each $\$ \mathbf{1 . 0 0}$.

ROSE MARIE. Buds long and pointed. Petals large and well rounded; the open bloom ideal as to form. One of the finest roses we know of for cut flower purposes. in color a delightful shade of pure, even rose pink.

Price each $\mathbf{7 5 c}$.

SOUV. DE GEORGES BECKWITH. Another masterpiece in rose production from Mons. Pernet-Ducher of Lyons, France, and quite in keeping with the high quality of his numerous other introductions. This rose is more or less of similar form to the well known variety Louise Catherine Breslau, but differs in its combination of colors, the latter being an exquisite shade of shrimp pink tinted chrome yellow, with shading of yellow at the basal portion of the petals. It is a strong, vigorous grower and to our mind will prove a desirable adjunct to any first class collection of roses. Price each $\$ \mathbf{1 . 0 0}$.

\section{Two Grand New French Roses}

The originator of these two roses, Mions. Pernet-Ducher of Lyons, France, and casily one of the foremost rose hybridists of the world today, regarded these two productions of his as the acme of his life work up to the time they were first distributed. They were so named to commemorate the names of his sons, Claudius and Georges, both of whom he lost in the great World War. No more fitting tribute could be paid to their memories.

SOUV. DE CLAUDIUS PERNET. A sensational novelty rose, in color a superb, clear sunflower yellow. Buds long and pointed, open flowers large and full. Wonderful as to stems, a vigorous grower with brilliant dark green foliage, which is resistant to mildew. Although recently introduced, this rose has gained great popularity in all parts of America and Europe. It is being forced at the present time by the hundreds of thousands as a cut flower and we know of no other yellow of its shade wherein the bud and open flower are of more perfect formation. Aside from its value as a forcing rose, it does splendidly in the open garden, bearing throughout the season elegant long stemmed flowers in a color which heretofore was practically unknown. It is one of the greatest advances by way of color ever offered to the public and is a striking example of the work accomplished in the modern hydridization of the rose.

Price each $\$ 1.00$.

SOUV. DE GEORGES PERNET. A companion introduction to the variety Souv. de Claudius Pernet, belonging also to the pernetiana class. A rose with a distinct and glorious color and one which is quite new in roses, being an unusual and exquisite shade of Oriental red, merging to cochineal carmine in the outer portion of the petals. There is a suffusion of yellow overlying the whole bloom. This remarkable combination, together with the exquisite bud form and handsome fully developed flowers, place this rose in a class by itself. The growth of the plant is moderate, but the flowers are freely produced during the entire season. Price each $\$ \mathbf{1 . 0 0}$. 


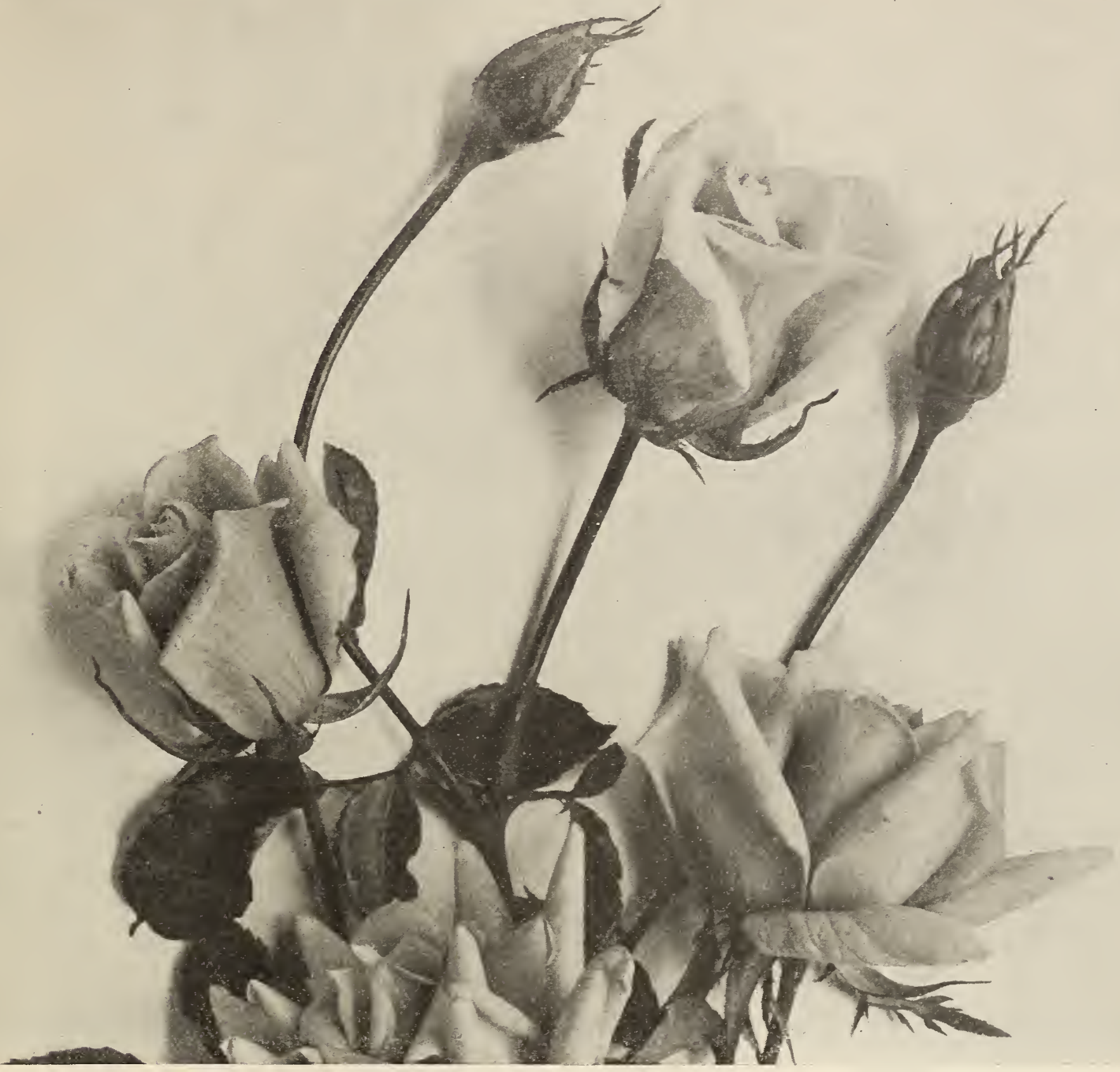

Mrs. W. C. Egan

WM. F. DREER (Howard \& Smith, 1920). We regard this rose as one of the finest which has been our good fortune to produce and introduce to the rose-loving public. It is a rose which through sheer merit is today recognized as one of the leading novelties of recent introduction. It won the gold medal at the show of the National Scottish Rose Society, held in Edinburg, Scotland, and has been awarded numerous certificates and medals in many other parts of the world. In general form it is almost a counterpart of Los Angeles, with much the same habit of growth, freedom of bloom, shape of flower, etc., but differs entirely in color, it being a deep golden yellow, heavily flushed and shaded deep peach and old rose. Very brilliant and delightful combination of colors not seen in any other variety. Agrand rose for cutting purposes. Price each $\$ \mathbf{1 . 0 0}$.

SOUV. de H. A. VERSCHUREN. This magnificent yellow rose might be described as a glorified Sunburst. The color is a wonderfully rich shade of apricot yellow shading to saffron at the edges of the petals. The buds are much larger than Sunburst and the flower if anything more perfect in form. It also has the additional advantage of being a strong rampant grower. One of the finest roses of this shade known in the rose world today.

Price each $\$ 1.00$.

THE QUEEN ALEXANDRA. A remarkable combination of color may be noted in this magnificent new rose.
A combination which is not only startling, but of peerless beauty as well. It is a two-toned rose with the upper side of the petals a glorious shade of vermilion, the reverse side being old gold. The petals of the flowers merge from vermilion to pure golden yellow at the base. The color effect to be noted in the fully expanded bloom, wherein these various colors manifest themselves in their entirety creates an impression of beauty in a rose that is not easily forgotten. Vigorous as to growth, free in bloom, exquisite as a cut flower under artificial light.

Price each $\$ 1.00$. 


\section{CLIMBING ROSES.}

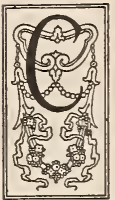

OMPRISED under this head is a list of varieties suitable for cultivation on walls, pillars, arches and trellises. Many of the varieties are not only of ornamental effect in the garden, but are also valuable for use as cut flowers, bearing splendid long stemmed buds. This is particularly true where they are sport climbers from bush roses of the same name.

Our plants this year are particularly fine, and if planted in early Spring will insure a plentiful display of blooms during the following summer and autumn.

AMERICAN PILLAR. A hybrid climbing rose belonging in the wichuriana section. The flowers are a lovely shade of bright carmine pink with a highly contrasting clear white eye. The blossoms are some two inches across and are produced in huge clusters, resembling in some respects a finished bouquet. This rose can-not only be treated as climbing rose, but makes a splendid cover on banks when pegged down.

Price each 75c.

BELLE OF PORTUGAL. A remarkably fine climbing rose introduced a few years ago, and one which has come into popular favor in all sections where it is possible to grow it. It is not a hardy rose and for this reason should only be planted in warm sections of the country. It will not stand any great amount of cold. This beautiful rose is a cross between the Burmese species, Rosa Gigantea and Reine Marie Henriette. The blossoms are very large, soft salmon pink in color. Supported singly on long stems. Its principal time of blooming is during the Spring, when the plants are literally covered with bloom. The color is truly one of the pastel shades. A variety of regal beauty. Price each \$1.00.

BLACK BOY. A recent introduction in climbing Roses from Australia and one of superlative beauty. This rose is the darkest colored climbing rose we have ever seen, being a very dark velvety crimson superimposed with rich maroon. It is a strong grower with handsome foliage and a constant bloomer.

Price each $\$ \mathbf{1 . 5 0}$.

CL. BELLE SIEBRECHT. A rampant growing climbing variety bearing immense buds and very large fully opened flowers. This rose is many shades darker than the well known variety Climbing Lady Ashtown and is equally as hardy in the colder sections of the country. Color rich dark rose, a pure and even shade.

Price each $\$ \mathbf{1 . 0 0}$.

Cli. CAROLine testout. A climbing form of Caroline Testout with the same silvery pink color to be noted in the mother plant. Remarkably free in bloom, the plants being literally smothered with perfect buds and flowers.

Price each \$1.00.

CL. CECIL BRUNNER. A sport from the well-known Cecil Brunner. Identical by way of color, with a tremendously vigorous climbing habit.

Price each 75 c.

CL. H. V. MACHIN. A climbing red rose of immense size with perfect bud formation and large well formed open blooms. The color is a glorious shade of scarlet crimson, during the Fall months more or less shaded with maroon. A strong vigorous growing variety very sweetly scented.

Price each \$1.00.

CLI. HOOSIER BEAUTY. A grand climbing form of the well known bush type. The blossoms are large, beautifully formed, rich crimson scarlet with shadings of maroon. Blooms freely produced over an extended season. Very vigorous.

Price each $\$ 1.00$.

CL. KAISERIN AUG. VICTORIA. Without a doubt the finest large flowered white climbing rose grown. Although a climbing rose, it is largely available for cutting purposes as the flowers are carried on fine, long stems.

Price each \$1.00.

CL. LADY ASHTOWN. A superb deep silvery pink -a shade or two darker than Caroline Testout. Unquestionably one of the grandest climbing roses in existence. Although a climbing rose, buds are borne on long stems, making it valuable as a cut flower.

Price each $\$ 1.00$.

CL. PINK CHEROKEE. A fac-simile in character of growth, form of flowers, etc., of the well known white type. Differs only in color, the latter being a soft shade of silvery carmine pink. Very beautiful and desirable climbing rose.

Price each 75c

CL. PINK MAMAN COCHET. One of our own introductions. The individual buds and flowers are much larger than those of the dwarf bush form and are produced in far greater profusion. An addition to pink climbing 1 oses which is worth while and bound to find its way into every garden where roses are appreciated and grown for their fragrance and beauty.

Price each $\$ 1.00$.

\section{LOS ANGELES. See page 2. \\ CL. RED RADIANCE. See page 2 \\ CL. SOUV. DE H. A. VERSCHUREN. See Page 2.}

CL. WHITE CHEROKEE. A variety grown in great quantities throughout California and is invaluable for hiding unsightly buildings, fences etc. It produces great masses of waxy white single flowers with a conspicuous bunch of yellow stamens in the center. Foliage shining green and good at all times of the year. Price each $\$ \mathbf{1 . 0 0}$.

CL. WHITE MAMAM COCHET. A white sport from the well known bush form and a fine companion to Climbing Pink Mamam Cochet. Buds of immense size, pure white, beautifully rimmed pink at the edges of the petals.

Price each $\$ \mathbf{1 . 0 0}$.

DOROTHY PERKINS, One of the best of the climbing polyantha roses. Rich, soft pink in color, producing at the terminus of the shoots large clusters of dainty blossoms. Of splendid effect when grown in pillar form.

Price each 75c

DR. W. VAN FLEET. A hybrid wichuriana rose of great merit. During the Spring the plants are a mass of exquisitely shaped buds and flowers. The buds are long and pointed. Ric? flesh pink in color. Splendidly adapted for a cutting rose, aside from the effect of its value as an ornamental flowering plant in the garden.

Price each 75 c. 
MARECHAL NEIL. An old time favorite sent out as long ago as 1864, but still much in demand. The flowers are bright golden yellow deliciously fragrant, but the blossoms are rery weak stemmed. It is a rose suitable for culture only in the warmer sections of the country, being quite tender. We would not recommend it generally to our customers, but when well grown it is a beautiful thing.

Price each $\$ 1.00$.

PAUL'S SCARLET CLIMBER. A comparatively recent addition to the list of climbers and one of superlative merit. The introduction of this rose has added an entirely new color to the climbing class, this being a wonderful shade of pure vivid scarlet, a shade which is at once intense and effective in it brilliancy. The plants when in full bloom are literally covered with flowers from top to bottom. It is a rose with scarcely any thorns; foliage, leathery and dark green, making a splendid foil for it = grand clusters of bloom. This rose is hardy in all sections of the county and should be largely planted. It is indispensable as a pillar rose or when used on pergolas, trelises, etc. A plant in bloom attracts attention at once.

Price each $\$ 1.00$.

RAMONA. A beautiful sport from the well known pink Cherokee rose. It bears great masses of flowers during the early. Spring season. The plants are well furnished with very dark green leathery foliage. The color is an exquisite shade of pure carmine lake, a color practically. unknown in any other climbing rose. This rose is particularly adapted for covering fences, trellises, etc. A plant in full bloom is truly a thing of beauty.

Price each 75 c.

SILVER MOON. Different from all other roses. Flowers very large, semi-double, $4 \mathrm{I} / 2$ inches in diameter. Pure white in color. Petals of great substance, beautifully cupped. The large bunch of yellow stamens in the center adds to its attractiveness The flowers are borne on strong stems 12 to 18 inches long and are delicately perfumed. The plant is a strong grower with rich glossy green foliage.

Price each $75 \mathrm{c}$.

THOUSAND BEAUTIES. Entirely distinct, not only in ramblers. but in climbing roses generally. The individual flowers are very large for this type of rose. In color it is the most delicate shade of soft pink. changing to carmine on the reverse of the peals when fully ex- panded. Borne in large clusters. A climbing polyantha rose of exceeding beauty. Price each $\mathbf{7 5}$ c.

WHITE BANKSIA. Flowers pure white, about one inch across; very double, borne in compact trusses, which literally cover the plant during its blooming season-i. e.. Spring. There are few roses more graceful in the climbing section than the Banksia roses. They are not hardy excepting in warm climates.

YELLOW BANKSIA. An exact replica of the white form above noted. Flowers clear canary yellow. Trusses large, exceedingly fragrant. A fine companion to the foregoing. Price each 75c.

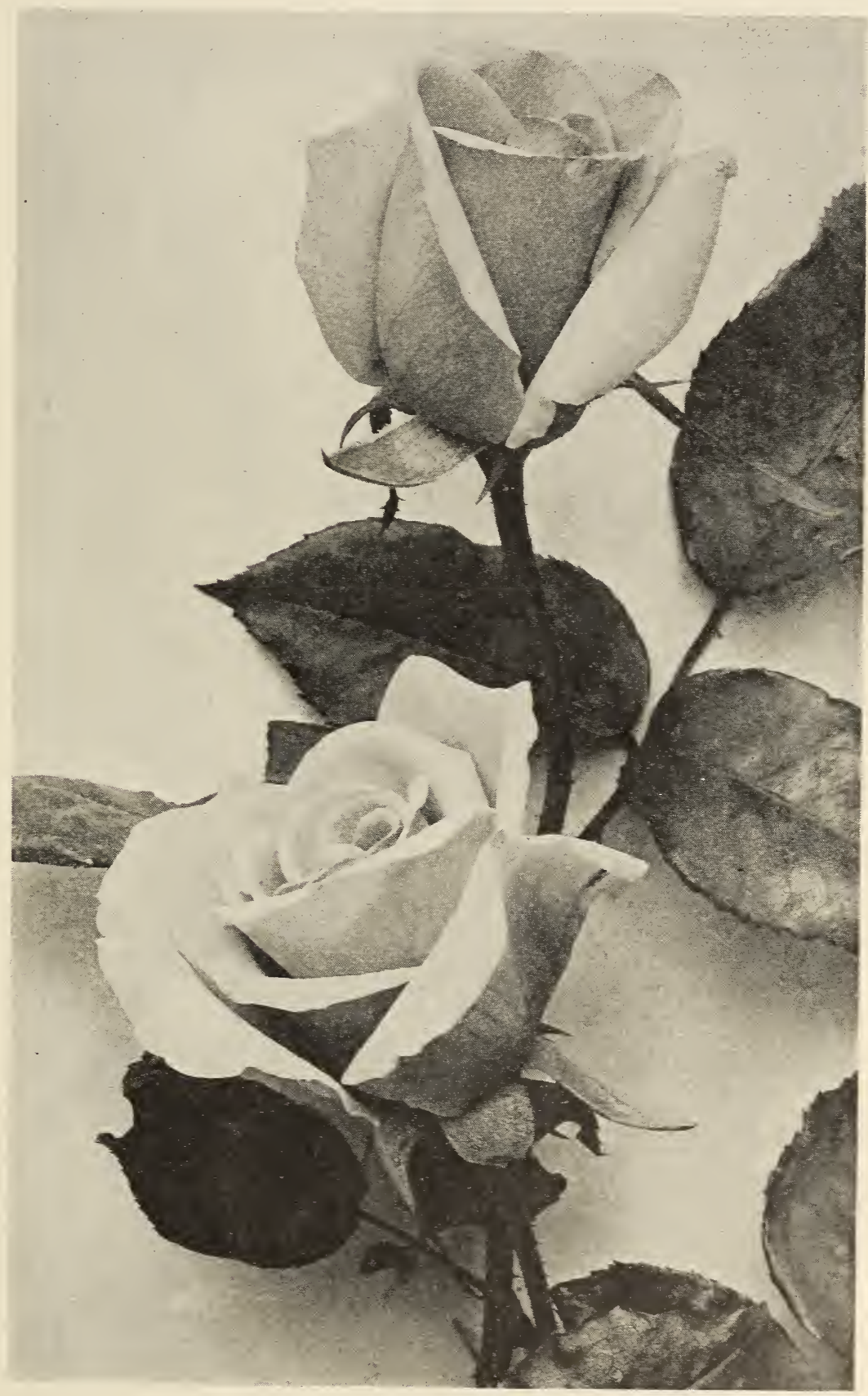

Mrs. Lovell Swisher (See page 5) 


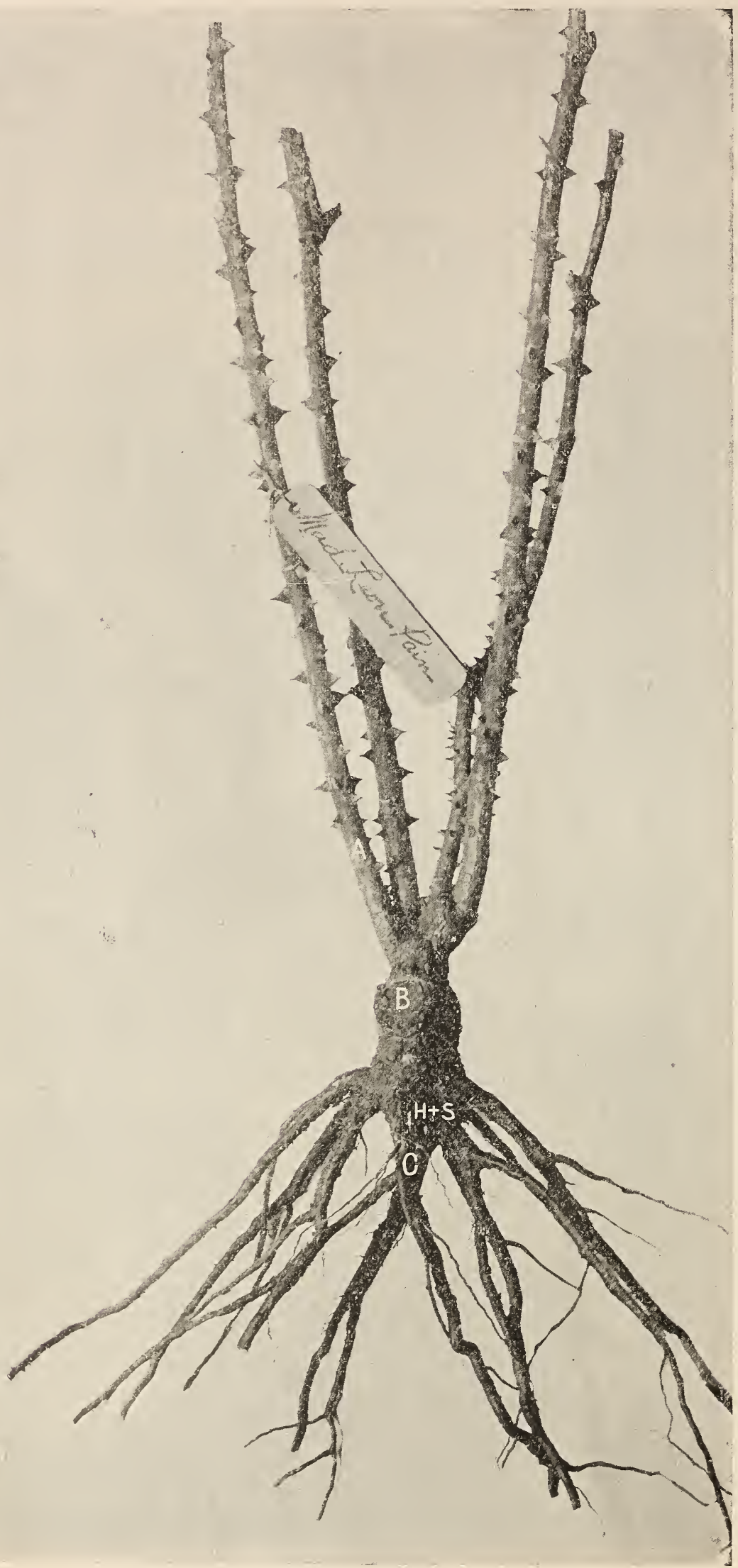

\section{How to Plant and Care for Roses}

Some of

the Most Important

Requisites for Success in

Growing Roses

Before entering into the technical details for which the treatise is intended we would impress on your mind the fact that plants are living things, and although not so far advanced in the scale of creation as the higher forms of animal organisms, yet in common with the latter, they develop in proportion as they are carefully and intelligently nurtured. A plant may suffer from cold; it is equally affected by undue conditions of heat or drought. It is subject to attack by insects and fun. gus pests, and resents in an unequivocal manner all factor: detrimsntal to its well-leing. It differs in no particular from man.

There are many who consider the placing of a plant in the soil as the last and most important act necessary to bring it to a point of fruition. As a matter of fact, this is the simplest prelininary. The after care, which it requires, comprised in proper pruning, watering, fertilizing, etc., is just as important of consideration if definite and adequate results are to be obtained.

The rose plants, which we offer you in this bulletin, have been carefully and scientifically grown. They represent the pent-up sunshine of two long California seasons. They are plants, which if you will study their needs and requirements as pertain to your own particular locality, will not only give you splendid results, but afford unbotinded pleasure to yourself and to all who love and appreciate nature, as expressed in the f lowe $r s$ of transcendentally beautiful roses. 
The varied climatic and soil conditions which pertain in different sections of our country make it exceedingly difficult to incorporate in these brief notes all that might be stated under the head of cultural directions, but contained herein will be found the fundamentals which, if you will follow them carefully and supplement them with your own experiences and ordinary attention, can be $d e p=n d e d$ upon to produce abundant crops of bloom.

A. CARE OF PLANTS UPON ARRIVAL: As soon as you receive the plants remove the various materials in which they are packed for shipment, excepting, however, the burlap which holds the damp spaghnum moss about the root action. This should be left on until the plants are ready for placing in their final growing quarters. If you live in a locality where the ground docs not freeze as for cxample, certain portions of the Southern States or the lower latitudes of the Pacific slope, the moss should be removed at once and the plants placed in the bed where they are to grow.

In the more northerly sections, where the ground is frozen and planting out impracticable, remove, as abore. all the packing except the moss and the burlap arcunrl the roots and bury the plants to the tips in a co.d frame. If a cold frame is not available, the dirt foor of an outbuilding, such as a shed or cool celiar, will answer. In any instance, cover the plants completcly with soil. Select a position where there is plenty of light, but not direct sunlight and no artifical heat whatever. Is soon as Spring breaks and it is possible is work the soil, plant them out in the garden. If the plants are to be buried, as suggested in the preceding paragraphs, it is adrisabic to wrap them in a picce or ordinary window screen, to guard ag inst the attacks of mice, etc.

B. LOCATION OF BEDS: Roses give the best results in a fully exposed, sunny situation where frec circulation of air is assured and, if possible, well removed from any buildings. It is inadvisable to plant them in even partial shade, as lack of sunlight induces leaf mildew in dull weather.

C. SOIL: Much has been said regarding the soil best adapted to roses, but our experience has been that they do well in almost any good, rich land with a strong preference to soils of a heavy nature.

D. PREPARATION FOR PLANTING: Given that a suitable plot has been selected, we now come to the main essentials to success.

The soil should be trenched or spaded to a depth of not less than 18 inches, breaking all lumps, removing all stones, etc. With this operation complete spread over it three or four inches of rotted manure. Spade in thoroughly, and when thoroughly incorporated, rake the bed to final grade.

Measure the distance apart plants are to be set, allowing two and one-half or three feet between them. At these designated points dig a hole 12 inches wide by ? feet deep; place in the bottom 8 inches of well-rotted manure, preferably cow manure, if obtainable. Tread this firmly. On top of this put 6 inches of well prepared soil, containing no manure whatever. Tread again to firm the layer of soil on manure. The remaining portion of the unfilled hole will now be ready to receive the plant.
If the roses are in a dormant or bare root condition, place them in the holes and carefully spread out the roots in as nearly natural position as possible, gradually filling in with fresh soil containing no manure whatever. Whenever the hole is completely filled, tread the soil around the plants as firmly as possible. Make a basin immediately surrounding the plant and water thoroughly

E. DEPTH OF PLANTING: The accompanying illustration shows a fair sample of one of our strong 2year-old budded roses bushes. B denotes the point of insertion of the bud in the original wild stock. A, the depth that the plant should be set in the soil. $C$ indicates the splendid root action to be noted in the class of roses which we send out. The tape measure to the left of the cut shows the point A to be about 4 inches above point $B$. Point $A$ is the proper height the soil should reach when the plant is finally set.

F. IVATERING: With the exception of an occasional syringing to clean the foliage of dust, roses should have little or no water overhead. Irrigation either by neans of shallow trenches running along the rows or by an individual basin around each p'ant are the best methods. This puts the water where it belones-at the roots.

In sections where there is small rainfall the plants should be kept moist during their entire growing scason. After each watering a liberal cultixation of the soil will prove highly beneficial and will tend to retain the moisture in the ground.

It is almost impossible to make any hard and fast rule in regard to the frequency of watering, as at times the heat and consequent evaporation is greater than at others. The principal thing to take note of is to sce that the soil is continually moist during the flowering or growing period. A mulch of well rotted manure, 2 or 3 inches decp over the entire surface of the bed, will help check evaporation and reduce the amount of water required.

G. PRUNING: The principal pruning should be done cither just after the plants have finished Summer growth - say in the months of November or December, or in very cold sections just before the sap begins to rise in the Spring.

It is diffcult to give full data as to the method of pruning, but it might be summed up as follows

Remove all small twiggy growths, pruning back to strong, well ripened canes which are well furnished with healthy, big dormant eyes. As a general thing, the entire top of the plant should be remored. The engraving shows a properly pruned hybrid tea, a 2 -year-old plant.

H. INSECTS AND DISEASES: Roses are affected with various diseases, pests, etc., but we will only treat of two which gives the most trouble. These are Aphis, or green fly, and mildew.

For the first use a strong solution of tobacco water, administered on a quiet evening with a spray pump.

For the second, take two ounces of slacked lime, mix with one pound sulphur, place in pot, add two gallons of rvater; boil for three or four minutes. The sulphur, insoluble in water, enters into solution through the action of the lime, forming a sulphurous solution. When cold, dilute this one part to five parts water and spray affected plants thoroughly. It is very effective. 
I. WINTER CARE: In sections where freezing conditions are severe, roses of all classes can be s?fely wintered in the open ground by hilling up around the plants with soil as far as possible and on top of this place a heary mulching of dry leaves, straw or other similar litter. Remove same as soon as d^nger of frost is over. After these details are taken care of, even the tenderest tea rose can bc wintered in the harshest Eastern climate. The hilling up of the plants or the covering with litter is quite unnecessary where heary freczing conditions do not prevail.

CLOSING NOTE: The Roses we offer are buddedworked low down on stocks with which we have found, by exhaustive experiments, they show an affinity. Some growers of own-root stock declare that budded Roses sucker from the wild stock. We have only to say, this is ignorance. Our stock is especially prepared for budding. They do not sucker; they produce stronger and better plants than any own-root stock possibly could and in addition, give an infinitely greater quantity of fine b!ooms.

\section{TIME OF DELIVERY}

We can supply roses as dormant or bare root plants any time from the first of November to the first of April. These are plants which are dug with their full root action from the field, the tops pruned back and all foliage removed.

\section{Howard $\mathcal{F}$ Smith Special Surprise Collections of Very Fine Roses}

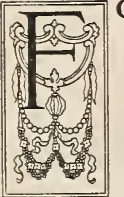

OR the benefit of our customers, especially for those who are not entirely versed in rose lore, the selection of varieties of ten becomes a puzzle. In order to a: $d$ them in their choice, we are offering these surprise collections. The roses comprised in these various sets are all different and not only embrace a full range of co'ors, but are of special value as regards price. In making up these collections we are giving you the benefit of a life-time experience and are certain that our choice will more than meet with your approval. In ordering these collections, it will simply be necessary to refer to the collection by initial. Customers living at a distance need not hesitate to order. The price which we have quoted on these includes all cost of packing and delivery to the nearest express office, but does not include any of the carriage ckarges. By our careful method of packing we can ship them to any point with the assurance that the plants will reach you in perfect condition. The time during which we can fill orders for these surprise collections is during that period when the plants are in dormant or bare root condition and ranges from the first of November to the first of April.

\section{SURPRISE COLLECTION "A"}

12 very fine novelty roses taken from our novelty list for the season of 1927 Strictly our own selection of varieties. Each one different. Carefully labeled for

$\$ 20.00$.

\section{SURPRISE COLLECTION "B"}

24 magnificent novelty roses taken from our 1927 novelty list, each one different, all carefully labeled. Our own selection

$\$ 39.50$.

\section{SURPRISE COLLECTION "C"}

12 of our choicest sorts suitable for a small garden. Strictly our own selection from the list of roses of recent introduction and the best of the tried and true standard varieties for

$\$ 7.50$.

\section{SURPRISE COLLECTION "D”}

24 of our choicest sorts suitable for a garden of moderate size-strictly our own selectionall different. Selected from the list of roses of recent introduction and the best of the tried and true standard varieties for

$\$ 14.50$.

NOTE-Customers ordering collection "C" or "D" are at liberty to specify the fact that they desire one or two climbing roses in the lot which would leave the collection, for example, 10 bush roses and 2 climbers, or 11 bush roses and 1 climber in collection "C." or 22 bush roses and 2 climbers, or 23 bush roses and 1 climber in collection "D." It is understood, however, that the selection of varieties is to be left to us.

SUBSTITUTION. It is almost impossible to forecast exactly what the demand will te for any particular Roses in our list, and sometimes we sell out early in the season. In placing orders, please state whether we are at liberty to substitute or not. Where we do this we will use every endeavor to give equally good or, if possible, better varieties. 